\title{
A Study on International Cooperation Information System of Universitas Negeri Medan
}

\author{
Maya Oktora ${ }^{1}$, Abil Mansyur $^{2}$, Winsyahputra Ritonga $^{3}$ \\ \{1 mayaoktora@unimed.ac.id, ${ }^{2}$ abilmpanjaitan@unimed.ac.id, ${ }^{3}$ winsyahritonga@unimed.ac.id \} \\ ${ }^{1}$ English Education Department, Universitas Negeri Medan, Medan, Indonesia \\ ${ }^{2}$ Mathematics Education Departement, Universitas Negeri Medan, Medan, Indonesia \\ ${ }^{3}$ Physics Education Department, Universitas Negeri Medan, Medan, Indonesia
}

\begin{abstract}
The realization of international cooperation managed by the International Office is still ineffective. The documents between parties involved is recorded in separate form of excel / word files, the process of compiling and searching data requires a long process and time. The work plan of the collaboration is also still experiencing problems, Universitas Negeri Medan (UNIMED) must require and record the desires of each party and collect the activity reports manually. This study aimed to analyze and design the web-based information systems of international cooperation in facilitating better preparation of documents, accelerate the search records and monitor the planned activities (work plan) to foster the efficacy of international cooperation in UNIMED. Stages and procedures for the implementation of the research includes the analysis of the documents, drafting the standard management and information systems, data retrieval, data analysis research, and design the information systems of international cooperation uses Waterfall, database design uses MySQL and the programming language uses PHP. The results show that the existence of a web-based international cooperation information system will be very helpful in the preparation of documents, accelerate the search for archives and monitoring work plans online.
\end{abstract}

Keywords: Waterfall, PHP, MySQL, Information System, cooperation

\section{Introduction}

Cooperation is an activity conducted by several institutions or people to achieve goals planned together. Cooperation between instances of either the school or College is done for certain purposes, for example to program scholarships, training, research, student and lecturer exchange, curriculum mapping, increased competence, accreditation, devotion to community, or with the purpose of improving Human Resources.

The government through the Ministry of Research, Technology, and Higher Education is being encouraged to enhance international cooperation between colleges in Indonesia and foreign partner institutions. It is stated in the strategic plan of Ministry of Research and Higher Education (Kemenristekdikti) 2014-2019 that this cooperation is intended to develop the quality and capacity of universities in Indonesia towards a World Class University.

APEC (Asia-Pacific Economies Cooperation) in year 2015 on Cross-border Education Cooperation on Higher Education Program also spawned the college international cooperation covering the areas of:

a. Increased mobility of students 
b. Increased mobility of researchers

c. The increased mobility of the education providers.

d. Increased networking of existing bilateral agreements.

As an integral part of Kemristekdikti's strategic plan to encourage the development of Indonesian universities towards the World Class University, Universitas Negeri Medan is consistently facilitating cooperative programs to improve its international position as a prestigious university. To this end, the Office of International Affairs is present and encouraging as well as running programs of internationalization under the coordination of the Vice Rector Office of the areas of Planning, Cooperation and Communication. The development and implementation of the international cooperation service performed as one of the flagship program that has begun since the year 2017 pioneered as institutional Strengthening of the Office of International Affairs (PKKUI). The program is compiled with the main objective to encourage units involved in running programs of internationalization with the Office of International Affairs.

However, problems in the implementation of international cooperation lie not only in the identification of shared goals and methods to achieve it, but also in the achievement of the goals. Cooperation can only be organised if the benefits are expected to outweigh the consequences to be borne by each party. In accordance with its objectives, international cooperation should be aimed at improving the welfare of the parties because the relations of international cooperation can speed up the process of improving welfare and solving problems between two or more countries.

In order to realize the cooperation activities, various efforts has been done to ensure that the activities are relevant to the development of the university, in line with the Development Plan of the State University of Medan, especially in becoming one of the World Class University in the year 2025. However, the implementation of the cooperation between Universitas Negeri Medan and universities or other institutions outside the country are currently not giving satisfying results because the existing cooperation program during this time are still separated, unsustainable and yet showing the optimum impact or significant for the university.

\section{a. International Cooperation Problems and the Solution Strategy}

The problem of international cooperation in Unimed not only lies in the identification of shared goals and methods to achieve it, but on the device and the achievement of the objectives of the instruments used. Cooperation should provide benefits for all stakeholders. In accordance with the results of the meeting of APEC (Asia-Pacific Economies Cooperation) about Cross-border Education Cooperation on Higher Education, international cooperation in universities should include improved mobility of students, an increased mobility of researchers, mobility of education providers, and increased networking of existing bilateral agreements.

The problems in managing the development of international cooperation Unimed in meeting APEC cooperation programme are formulated as follows:

First, how to develop of the good governance of international cooperation in supporting Unimed towards the goal as a World Class University?

Second, how do the information system of international cooperation support the activities of international cooperation? 
To encourage the development of the international cooperation service in Unimed, related research development in services and information systems for international cooperation need to be created as a broader interdisciplinary interests with overseas partners. Expected output in the form of service governance and development of the concept of information system field of international cooperation the standards and accountability on an ongoing basis and can be accessed through the official State University of Medan.

\section{b. An overview of the State University of Medan}

The vision of the State University of Medan (Unimed) is: to become a leading university in education, engineering industry and culture. This vision was set since IKIP Medan changed become UNIMED in 1999. The excellence in education is realized through the holding of a quality education. Basic and applied research are balanced based on the real needs of stakeholders and community-based income generate. As an Institution of Education for Teacher Training (LPTK), Unimed has a responsibility to produce quality teachers. Educational research policy must be based on the real needs in schools to enrich the field of educational materials and innovations-based learning and student active learning. As the only Public LPTK in North Sumatra, Unimed has become the center of consultation to solve problems in education, because generally the competence of graduates for all levels, types and lines of education in North Sumatra has not yet meet the SNP.

Referring to the University's vision, the Office of International Affairs $(K U I)$ then formulate a vision of "Realizing the vision of the university to excels in the fields of education, engineering industry and culture through institution internationalization ". To realize the vision set out above, 5 missions, namely: (1) organizing quality education, research, and community service; (2) develop Unimed into teaching and research institution; (3) developing the culture of entrepreneurship; (4) the fostering of scientific culture; and (5) fostering an atmosphere of academic and organizational climate. The mission was carried out to achieve the goal of Unimed as follows: (1) produce superior graduates and professionals; (2) generate, develop, and disseminate science, technology, art; and/or (3) generate and develop innovative and productive works.

In accordance to the mission, to realize the vision of $K U I$ and Unimed, then the missions of KUI Unimed are set out as: (1) to Facilitate a quality education service for foreign students; (2) Conducts research and publishing scientific papers internationally; (3) organizing community service lecturer and students in order to study abroad, Exchange programs, as a result of the implementation of the science and technology invention which solve excels in regional and national development; (4) implementing development programs include academic program development and research, human resources, management of the University and the promotion of the University; (5) develop a network of international cooperation; and (6) hosted foreign students service system of good quality.

Structuring research activities beginning with the determination of the direction of policybased resolution of the stakeholders with the principle of income generating. To obtain optimal results, these activities are designed to involve the potential cost, human resources, and facilities and infrastructure. The construction of learning community and research attempted by involving scientific a strong leader, able to work hard, diligent, thorough, militant, an academic, and has an open, honest, democratic, and critical thinking.

The research field of non education geared to solving industry and tourism. The research of products expected to be empirical grounding for the industrial sector and tourism to increase the GDP. This product will serve as a cornerstone of cooperation partnerships 
between Unimed with community groups, industry, and government. In addition, the research results can be used to enhance the bargaining position of Unimed in the eyes of stakeholders.

The issue of globalization certainly caused the advancement and development of science and technology. With respect to that issue and indeed the reality must put higher education in work to draw up the draft of programs and activities that would likely to be achieved. This situation led to the role of higher education institutions that had been transformed into the comparative competitive nature. So that the quality and relevance, accountability and autonomy, which is based on self assessment evaluation. noteworthy should be achieved. When development of teaching and research in Unimed excels, the institution made a commitment at the level of leadership through innovative policies.

Lecturers are directed to conduct research-based education research based on the real needs in the field. The results of such research could be used for the development of sociocultural-based learning, the design and implementation of the application of the contracts lectures, web-based learning, project-based learning, research-based learning, critical book report, portfolio teaching, and laboratory management. The research of the education system to produce effective, efficient, and quality will also be conducted to improve Unimed's role as the institution produce educators (LPTK).

\subsection{International cooperation}

The article 50 of the Law of the Republic of Indonesia number 12 of the year 2012 of higher education set the "international cooperation of higher education" that encourages colleges in Indonesia to develop international cooperation covering the areas of Education, research, and Community Service; and also to develop international cooperation based on equality and mutual respect by promoting science, technology, and values of humanity that gives benefits to human life. Next Article 90 of that Act States that the Organization of higher education by College of other countries can be made to the provisions of obtained the permission of the Government, non-profit, principled, cooperate with Indonesia over College Government, and give priority to citizens

The main purpose of international cooperation is to meet national interests not yet owned in the country. To that end, those countries need to fight for national interests internationally. In that regard, a collaboration is required in order to bring together national interests among countries. International cooperation carried out should at least have two main requirements: first, the necessity to respect the national interests of each of the members involved. And second, the existence of a joint decision in overcoming any problem arise. To reach a decision together, communication and consultation are required on an ongoing basis. The frequency of communication and consultation must be higher than commitment [1]

K. J. Holsti, (1988) states that international cooperation can be defined as follows:

a) The view that two or more interests, values, objectives meet each other and produce something, promoted or fulfilled by all sides at once.

b) Expectations of a nation that policies decided by other countries will help the country to achieve its interests and values.

c) Agreement on specific issues between two or more countries in order to exploit the equation of interests.

d) Set of transactional rules about future implementation of an agreement.

e) Transactions between countries to meet their needs and approval. 
International cooperation was not only done between countries in an individual basis, but also between countries that take shelter in organizations or international institutions. Regarding international cooperation, Koesnadi K. said that international cooperation framework is a result of the relationship of interdependence and growing complexity of human life in the international community [2]

Holsti KJ (1988) in International Politics, A Framework for Analysis also argues that: "International relations may refer to all forms of interaction between the members of separate societies, whether sponsored by the government or not, the study of international relations would include the analysis of foreign policies or political processes between the nations, however, with its interest in all facts of relations between distinct societies, it would include as well studies or international trade, transportation, communication and the development of international values and ethics".

There are several goals of cooperation in the field of higher education which is carried in the meetings of APEC (Asia-Pacific Economies Cooperation) about "Cross-border Education Cooperation in Higher Education", which are: increased mobility of students; the increased mobility of researchers; the increased mobility of the giver of the education service (education providers); increased networking of existing bilateral agreements.

The implementation of international cooperation not only lies in the identification of shared goals and methods to achieve it, but lies in the achievement of the target. Cooperation will also be sought if the benefits are expected to outweigh the consequences should he bore. In accordance with its objectives, international cooperation aimed at improving the welfare of together. Because of the relationship of international cooperation can speed up the process of improving welfare and solving problems between two or more countries.

\subsection{International Cooperation the State University of Medan}

To support Unimed towards its goal as a World Class University in 2025, facilitating consistent programmes of international cooperation for improving its bargaining position in the eyes of the world is one if its main duties as an international institution. One of the flagship program that has begun since the year 2017 pioneered is a program of institutional Strengthening of the Office of International Affairs (PKKUI). The program is compiled with the main objective to encourage units involved in running programs internationalization through the Office of International Affairs, under the Office of the Vice Rector of Planning, Cooperation and Public Relation.

International cooperation in Unimed is defined as the cooperation between Unimed with other colleges or institutions abroad. The range of the programs may vary from staff exchange, student exchange, joint research, publishing papers together in joint publication, joint supervision to the organization of scientific meetings, students' internship, provision of scholarship and the utilization of shared resources.

The programs of international cooperation are specifically aimed at preparing students to take parts as member of global society Unimed supports world peace through internalization while enhancing and strengthening nationalism. In this regards, international cooperation aims to:

a. Improving the quality of graduates Unimed in building knowledge-based society that are able to enter the job market with an international multi-lingual skills, communication skills, negotiation, cultural understanding and diplomacy between countries,

b. Promote the development of knowledge-based economy, and 
c. Increase the ability of Indonesia and to answer the challenge of human development and the achievement of Sustainable Development Goals (SDGs).

The Organization of Compulsory Cooperation Programs meet the conditions outlined in the General Administration of Higher Education, the provisions of national law, and international law in force. The Organization of the International Cooperation Program is implemented based on 5 principles:

1) Give priority to the interests of national development and contribute to the improvement of the nation competitiveness;

2) Equality and mutual respect, which means that Unimed build partnership with other universities or institutions abroad with the aim of improving the performance of higher education programs. Therefore, the partnership can only be implemented when the overseas colleges have registered and accredited by a recognized accrediting agencies in the country.

3) Added value in terms of improved quality of education, meaning that the cooperation should be built in an innovative, creative, synergistic, and fill each other in order to provide added value in the form of an increase in the quality of higher education in Unimed;

4) Sustainable, means cooperation should provide equal benefits for Unimed and parties who cooperated and implemented on an ongoing basis. Cooperation should also give benefits to stakeholders and contribute in building peace, national and/or international. In addition, cooperation should also be extended to other parties;

5) Diversity, meaning that cooperation should consider cultural diversity that can be cross-regional, national and/or international.

The scope of this research is limited to the development of the conceptual design and specification of system requirements. Research results can be followed up with further activities such as the detailed design, system development, testing and training.

Stages of research are divided into 3 parts namely the identification of needs, the current service evaluation and recommendations the new system with the scope as follows:

Stages of research are divided into 3 parts, namely the identification of needs, the current service evaluation and recommendations the new system with the scope as follows: To get requirements from stakeholders related to the service and information system cooperation abroad; to evaluate the Standard Operation Procedures and identify the role of the information systems services for international cooperation; to evaluate the status of the service and the existing information system; to develop a conceptual design of the information system of international cooperation; to draw up recommen-dations for the stages of development of information system of international cooperation in the future.

The problems faced by the international office of Unimed is the weak governance and information system services that can interfere with the purpose of Unimed towards World Class University. This is due to unsufficcient handling of document governance and information system of international cooperation. The expected products of this research are the realization of international cooperation and governance of information systems for international cooperation. To boost the publication of Unimed, the another output of this research is the publication in national or international journals. This will greatly contribute to the development of international cooperation that will have significant impact towards Unimed as a World Class University. 


\section{Methodology}

The methods used in this research is a method where the waterfall approach is done systematically and sequentially in software development, beginning with needs analysis stage, the stage of planning, modeling, construction as well as the delivery of software/system information to the user [1].

In this research the steps do not come to the delivery of the software to the user. The steps used in this stage are the requirements, analysis, design, coding and testing. As for the explanation is as follows:

First, requirements. At this stage, data collection and determination of the system needs to be built by observation, interview and study of literature. The observation is done by doing a direct observation on the research object, in this case, cooperation partners, stakeholders on matters relating to the MoU process. The interview was conducted to the staffs of International Office to find out about the agency profile, information and cooperation of other things that needed to be clarified related data collection. A literature study was also conducted to find reference theories that are relevant to this study. Reference used comes from books, journals, articles, research reports or websites on the internet that deals with the design and creation of information system of international cooperation at Unimed.

Second, analysis. At this stage the system flow analysis performed the same work in progress at $U N I M E D$ then conducted an analysis of the data obtained to produce the things that are required for the software to be built in manufacturing information system international cooperation in UNIMED.

Third, design. At this stage, the translation of needs or data that has been analyzed for information system of international cooperation will be done to further design the user interface or display system in a way to make it easy to use by the user.

Fourth, coding. At this stage, the data for problem solving feature that has been designed will be translated into a programming language. The programming language used is PHP.

Fifth, testing. The last stage of testing is done with the Black Box method and trial against information system web-based cooperation to see the compliance with the needs of the stakeholders work together and to find whether there are still mistakes by doing testing in the form of User Acceptance Test.

\subsection{Research Procedure}

This research procedure will be divided into three parts, where there are several stages that need to be performed on each part. The following is a description of each section:

Identification of Needs. This took place in the early stages. At this stage, the needs of the service activities of the system to be implemented will be collected. The output of this stage is the progress report which includes a list of features and functions that will be implemented.

Interview. In order to collect requirements from all parties contribute, some universities abroad involved in the cooperation will be interviewed. The output of this process is a transcript of the interview that will be used as input to the next process.

Mapping service model. The entire transcript of the interviews conducted with stakeholders will be interpreted into technical and terminology that will be mapped into a model of the information service. The output of this process will be discussed in an FGD attended by policy makers at university level. FGD needs to be done to ensure that the process of the activity that has been modeled is in accordance with a model of the actual activities in the system. 


\subsection{Evaluation of the current governance and information systems}

In understanding the situation of international cooperation system that exists today, the observation on the situation in the field needed to be done. In this section, the research team will examine the SOP to get basic information from a service that is already done. The output of this part is a document that describes which information technology can play a role in internatioal cooperation framework.

Review of current SOP. The current Standard Operation Procedure (SOP) needs to be examined to get a better understanding on the interaction of the existing systems. By doing a study on the SOP, it can be expected that the larger picture of how the system is running at the momen tis obtained. The results of the study will provide sufficient information related to interaction patterns that exist today. This information will be used to create a baseline of the system. Thus, it can be seen that the contribution of information technology that required a new system may not function as expected. Conceptual Design can be compiled based on the information obtained from this stage.

\subsection{The Development of International Cooperation Information Systems}

Specifying the features and functions of the information system. Based on the results of the previous phases, the obtained informations are about what are the features of the foreign partners need and how the existing system is currently running. It will recommendations of the new system for the framework of cooperation services abroad will be drawn up. The output of this part is the specification of the application information system that will be developed, which contains a list of the features and functionality of the system and how they should interact with its users [2].

Concept Design Recommendations was drafted based on the specifications of the foreign cooperation information systems that have been developed previously. In order to realize the concept design, some steps will be compiled and taken for implementation.: (1) two limited tests were carried out on small groups; and (2) field tests (testing fields).

\section{Result and Discussion}

The current system that is running in UNIMED on organizing cooperation could not be said to be optimal. Currently, the data between the organizer of cooperation and the parties involved are noted in the form of word/excel files separately and have not integrated with each other so that the process of data retrieving in a specific time period requires a long process and time.

Preparation of the working document is the same as Letter of Intent (LOI), a Memorandum of Understanding (MoU) and a Memorandum of Agreement (MoA) or $n$. agreement also experience obstacles because the data organizer still separated and not yet well organized. When there is a lack of data in the preparation of the document then the international office should contact the related institutions to find the missing information and rearrange the new document formats. In addition, the plan of activities (work plan) done by the organizer of cooperation still have plenty of constraints. UNIMED must communicate intensively through various platforms to get the work plan clear. 
After the agreement held, documents relating to the same work scanned and saved again. When required by the user then to look back manually. This requires a very long time waiting.

International cooperation information system is a great alternative to help manage data and documents relating to cooperation. In this information system will be developed that is based website. The organizer of cooperation can access account information and see the International Office anytime and from anywhere [3]. This is very helpful International Office in optimizing data management, drafting documents and archive documents for various purposes in UNIMED.

\subsection{System Requirements Analysis}

\subsubsection{User needs analysis}

User needs analysis on information system of cooperation based on the results of the interview are as follows:

a) Admin

1. Need for login form

2. Are expected to show the number of new applicants, the filing of new cooperation, the total number of partners and UNIMED news on dashboard of Admin.

3. Manage registration data partners of cooperation.

4. Do the filing.

5. Perform management and submission discussion cooperation.

6. Template document management.

7. Generate and print the document.

8. Perform records management document.

9. Perform management and discussion of work plan.

10. Perform data management news cooperation.

11. Manage data on borrowed MoU documents.

b) Partners

1. Need for registration form.

2. The need for login form.

3. Able to see and offer information, news about the number of partners and UNIMED.

4. Able to see the data of partners

5. Filing of a form of cooperation.

6. Confirm discussions and cooperation.

7. Perform management and discussion of work plan.

8. Print documents of cooperation.

9. Download file from archive.

\subsubsection{Functional Need Analysis}

A functional needs analysis in information system of cooperation are as follows:

a) Admin

1. Admin can manage the registration data.

2. Admin can manage data submissions.

3. Admin can manage data workplan.

4. Admin can manage the data template documents.

5. Admin can do generate documents.

6. Admin can manage the archived data. 
7. Admin manage data news.

8. Admin can manage data on loan documents.

9. There is a comment form for discussions on submissions and work plan of cooperation.

b) Partners

1. Login functionality for each user.

2. The partner can do the registration.

3. The partner can do the same work.

4. Partners can view documents and data archives.

5. There is a comment form for discussions on submissions and work plan of cooperation.

\subsubsection{Analysis Of Non-Functional Requirements}

Non-functional needs analysis in information system of cooperation are as follows:

a) display the alert on a specific action action.

b) Use responsive template.

\subsection{The Draft Infrastructure}

Infrastructure of information systems of cooperation in conducting the two entities have access to System i.e. Admin and partners. Partners can register into the system, once verified by admin next partners can fill the work plan and view information, while Admins can manage, print, archive documents and after that the MoU signed by both documents parties.

As for the data that flows from the Admin's are data entities login, account verification data registries, data template documents, filing data collaboration, data submission and discussion of the work plan, the data archive of documents, data and news data document the borrower's cooperation [4]. In addition to the data that flows from the partners is registration data collaboration, data, documents, data, data, workplan discussions, news and data collaboration [5].

\section{a. Implementation of the System}

1. Login page.

Login page taking text input as username, password and verification. The system classifying level users. The user as Admin would be directed into the system Admin as user as Partners will be directed into the page system Partners.

2. Registration page. Interface

a. On the registration, the Registrar is able to fill in the registration form data, upload the logo of the institution and complying with the registration statement. In addition on this page are also available knobs for heading home page.

b. The Admin Dashboard and partners.

After the Admin login successfully then the first page shown is the Admin dashboard page. On this page there is a registrant verification menu, menu, menu account management create a new submission, the submission confirmation menu, menu management, generate cooperation and archive the work plan, menu, menu management news and menu of loan documents. Dahsboard view partners, partners can see information about the self profile, a link to the partner institution partners and partners can view information from faculty or MoA bid unit at UNIMED as well as 
news and documentation cooperation.. The menu in the dashboard main menu i.e. the Partner page, menu, menu edit partner profile profile, view menu, menu partners create new filing, the menus offer cooperation, document and archive menu, menu and menu news workplan.

c. Display the management Work Plan. On the page Work Plan, users can view, add, upload, and delete the archived data in accordance with the filing. Furthermore, in this page users can also discuss about the work plan based on the submission of the same work.

Generate a Display and print the document. Admin can print or save the document after you successfully generate documents. Partners that terlibatdalam filing a partnership can also save and print a document of cooperation.

\section{Conclusion}

Based on the results of the design in this research, the following conclusions are: Information systems organized international cooperation can help in preparing documents statement of cooperation between organizers involved in the submission of the same work. This cooperation information system can save the archives document the statement of cooperation which UNIMED has done with partners. Cooperative information systems can assist in creating a work plan that can be monitored online.

\section{Suggestions}

As for suggestions that can be done if the system is used are:

a. System security must be observed so that the system can be maintained from other parties who are not interested.

b. Need to be made of the existence of the system back up and restore the database to back up or manage database.

c. Need to be made of the existence of the notification notice the latest activities to facilitate the checking or confirmation activities.

\section{References}

[1] R.S. Presman, Rekayasa Perangkat Lunak (Pendekatan Prakstisi). Jogjakarta: ANDI Offset, 2012.

[2] S. A. K. and Siahaan, "Analisis dan Perancangan Sistem Informasi Manajemen Arsip Berbasis Web Pada Sekolah Tinggi Ilmu Tarbiyah Kabupaten Tebo,” J. Manaj. Sist. Inf., vol. 1, no. 1, pp. 1-10, 2016.

[3] Sumardi K and Widyatmoko, "Perancangan Sistem Informasi Kearsipan Kopertis Wilayah VI Semarang," Techno, vol. 11, no. 1, pp. 37-46, 2012.

[4] T.W.A. Putra and Q. Shinta, "Rancang Bangun Aplikasi E-File Sebagai Sarana Pengumpulan Data Dosen," in Science and Engineering National Seminar, 2015, vol. 1, no. 1, pp. 331-344.

[5] B.Uddin and R.Yuni, "Sistem Informasi Pengelolaan Arsip Digital (SIPAD) Berbasis Web," in Seminar Nasional Teknologi Informasi dan Komunikasi Terapan (SEMANTIK), 2015, pp. 8388. 